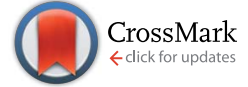

Cite this: RSC Adv., 2017, 7, 13072

Received 19th January 2017

Accepted 21st February 2017

DOI: $10.1039 / \mathrm{c} 7 \mathrm{ra00799j}$

rsc.li/rsc-advances

\title{
Synthesis, optical and electrochemical properties, and photovoltaic performance of a panchromatic and near-infrared (D) $2-\pi-A$ type BODIPY dye with pyridyl group or cyanoacrylic acid $\uparrow$
}

Yousuke Ooyama, * Masahiro Kanda, Toshiaki EnoKi, Yohei Adachi and Joji Ohshita*

\begin{abstract}
(D) $)_{2}-\pi-A$ type boron dipyrromethene (BODIPY) dyes OMK-PY and OMK-CA bearing a pyridyl group or cyanoacrylic acid group, respectively, at the end of 8-positions on the BODIPY core, as an electronwithdrawing anchoring group to adsorb onto the $\mathrm{TiO}_{2}$ electrode and two diphenylaminethienylcarbazole moieties as an electron-donating unit at the 3- and 5-positions on the BODIPY core, were designed and developed as a photosensitizer for dye-sensitized solar cells (DSSCs). It was found

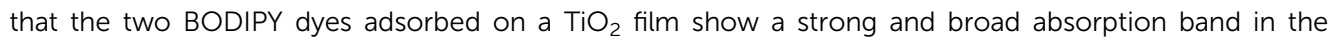
range of 600 to $850 \mathrm{~nm}$, and the onset of the absorption band reached $900 \mathrm{~nm}$, that is, OMK-PY and OMK-CA possess the near-infrared (NIR) adsorption ability as well as the panchromatic adsorption ability, and good adsorption ability onto the $\mathrm{TiO}_{2}$ electrode. Moreover, cyclic voltammetry demonstrated that the two BODIPY dyes show two reversible oxidation waves, thus indicating that the redox processes of OMK-PY and OMK-CA are very stable. On the basis of the experimental results and density functional theory calculation, we propose that the $(D)_{2}-\pi-A$ BODIPY structure with two diphenylaminethienylcarbazole moieties as strong electron-donating units at the 3 - and 5-positions on the BODIPY core is an effective strategy to lead a high light-harvesting efficiency (LHE) in the range of visible light to NIR light, although the DSSCs based on $(D)_{2}-\pi-A$ type BODIPY dyes that have been developed in this current stage showed low photovoltaic performances.
\end{abstract}

\section{Introduction}

Dye-sensitized solar cells (DSSCs) employing dye-adsorbed $\mathrm{TiO}_{2}$ electrodes have made a hopeful impact on chemists, physicists, and engineers as one of the most promising new renewable photovoltaic cells in the last quarter of a century, ${ }^{1-8}$ since Grätzel and co-workers reported high-performance DSSCs employing a Ru-complex dye-adsorbed $\mathrm{TiO}_{2}$ electrode in 1991 . $^{9}$ In particular, much effort has been made on the development of various types of $\mathrm{D}-\pi-\mathrm{A}$ organic dye sensitizers which are constructed of a diphenyl- or dialkylamino group as the electron donor (D) and a carboxyl group, ${ }^{10-16}$ 2-(1,1-dicyanomethylene) rhodanine, ${ }^{17}$ pyridine,${ }^{18-21}$ or 8 -hydroxylquinoline ${ }^{22}$ as the electron acceptor (A) and anchor linked by $\pi$-conjugated bridges, and there has been a gradual accumulation of information about the relationship between the chemical structures and the photovoltaic performances of DSSCs. As a result, DSSCs have achieved a solar energy-to-electricity conversion yield $(\eta)$ of up

Department of Applied Chemistry, Graduate School of Engineering, Hiroshima University, Higashi-Hiroshima 739-8527, Japan. E-mail: yooyama@hiroshima-u.ac. jp; Fax: +81-82-424-5494

† Electronic supplementary information (ESI) available. See DOI: $10.1039 / \mathrm{c} 7 \mathrm{ra00799j}$ to $13 \% .^{11 c, \boldsymbol{d}}$ However, one of the challenges to further improve the photovoltaic performances of DSSCs lies in the enhancement of light-harvesting efficiency (LHE) in the near-infrared (NIR) region (780-1000 $\mathrm{nm}$ ) as well as visible region of the solar spectrum. Some boron dipyrromethene (BODIPY) dyes which are electrochemically modified through the introduction of electron-donating and electron-accepting groups onto the BODIPY core, possess panchromatic absorption ability because of their high photoabsorption coefficient in the visible region of the solar spectrum..$^{23-25}$ Actually, Akkaya et al. have designed and developed a series of D-A-substituted BODIPY dye sensitizers, which have two triphenylamines as electron donors at the 3and 5-positions and benzoic acid as electron acceptor at the 8position. The D-A-substituted BODIPY dyes showed a strong and broad absorption band in the range of 650 to $850 \mathrm{~nm}$ with the absorption maxima at around 720-760 $\mathrm{nm}$ (molar extinction coefficient $\left.(\varepsilon)=60000-70000 \mathrm{M}^{-1} \mathrm{~cm}^{-1}\right) .{ }^{23 d}$ However, almost all BODIPY photosensitizers reported so far show the photoabsorption band in wavelength region shorter than $700 \mathrm{~nm}$.

Thus, in this work, to explore effective BODIPY dye sensitizers possessing a high LHE in the range of visible light to NIR light, we have designed and developed (D) $)_{2}-\pi-\mathrm{A}$ type BODIPY dyes OMK-PY and OMK-CA bearing pyridyl group and 


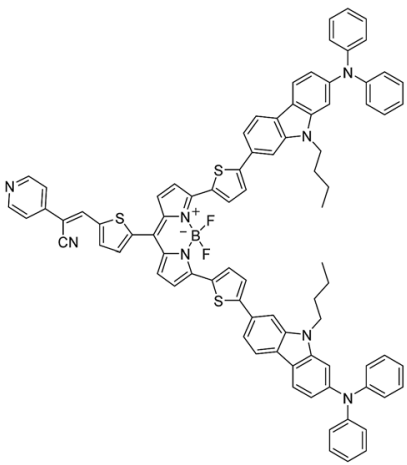

OMK-PY

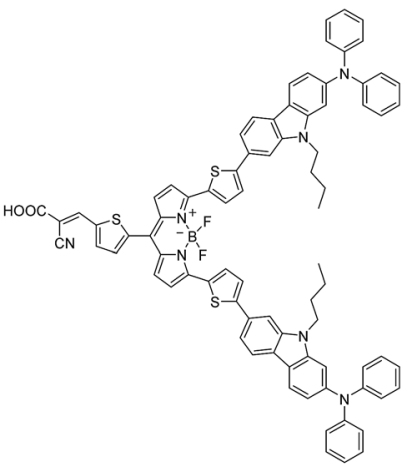

OMK-CA
Fig. 1 Chemical structures of $(D)_{2}-\pi-A$ type BODIPY dyes OMK-PY and OMK-CA

cyanoacrylic acid group, respectively, at the end of 8-positions on the BODIPY core, as an electron-withdrawing anchoring group to adsorb onto the $\mathrm{TiO}_{2}$ electrode and two diphenylamine-thienylcarbazole moieties as an electron-donating unit at the 3- and 5-positions on the BODIPY core (Fig. 1). Here we reveal the photophysical and electrochemical properties of the $(\mathrm{D})_{2}-\pi-\mathrm{A}$ BODIPY dye sensitizers and their photovoltaic performances in DSSCs, based on photoabsorption (dye solution and dye-adsorbed $\mathrm{TiO}_{2}$ film) and electrochemical measurements (cyclic voltammetry), density functional theory
(DFT) calculation, FT-IR spectroscopy of the dye-adsorbed $\mathrm{TiO}_{2}$ film, photocurrent-voltage $(I-V)$ curves, and incident photon-tocurrent conversion efficiency (IPCE) spectra. We demonstrate that the $(\mathrm{D})_{2}-\pi-\mathrm{A}$ type BODIPY dyes possess the NIR adsorption ability as well as the panchromatic adsorption ability.

\section{Results and discussion}

\section{Synthesis}

(D) ${ }_{2}-\pi$-A BODIPY dye sensitizers OMK-PY and OMK-CA studied in this work were synthesized according to a stepwise synthetic protocol (Scheme 1). Indeed, the (D) $)_{2}-\pi-\mathrm{A}$ BODIPY dyes were successfully prepared by using Stille coupling to introduce the electron-donating unit (two diphenylamine-thienylcarbazole moieties), and then by using Knoevenagel condensation to introduce the electron-withdrawing anchoring group (pyridyl group or cyanoacrylic acid group). Dipyrromethane 2 was prepared by condensation of compound 1 (ref. 26) with pyrrole with TFA added as a catalyst. The dichlorinated compound 3 was prepared by chlorination of 2 with $N$-chlorosuccinimide (NCS) followed by oxidation with DDQ. Compound 3 was reacted with $\mathrm{NEt}_{3}$ and treated with $\mathrm{BF}_{3}-\mathrm{OEt}_{2}$ to afford the BODIPY 4. Compound 6 was prepared by Stille coupling of 4 with stannanyl compound 5 (ref. 18g). Compound 6 is hydrolyzed by treatment with acid to generate the aldehyde 7. BODIPY dye OMK-PY was prepared by reacting 4-pyridylacetonitrile hydrochloride with the compound 7 in the presence of $\mathrm{NEt}_{3} \cdot{ }^{27}$ BODIPY dye OMK-CA

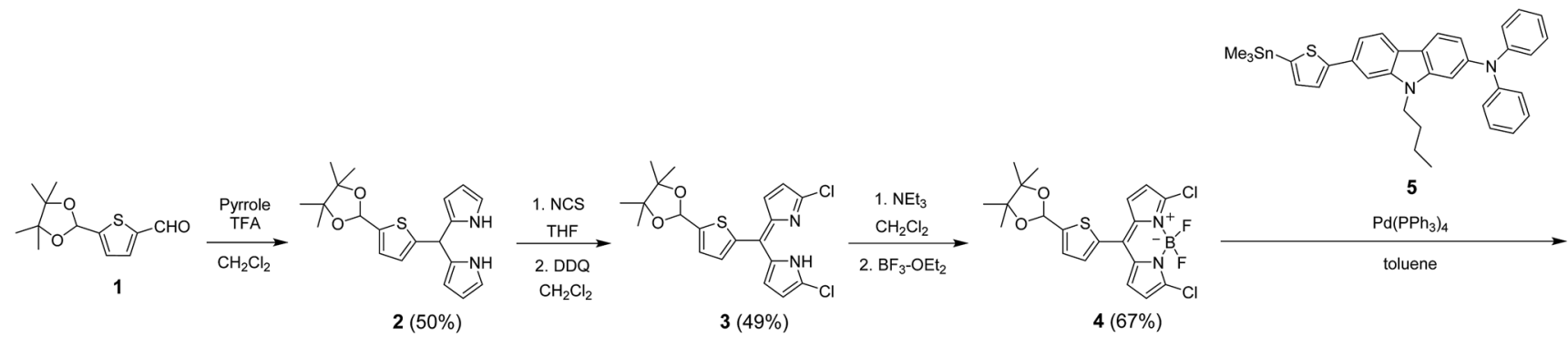

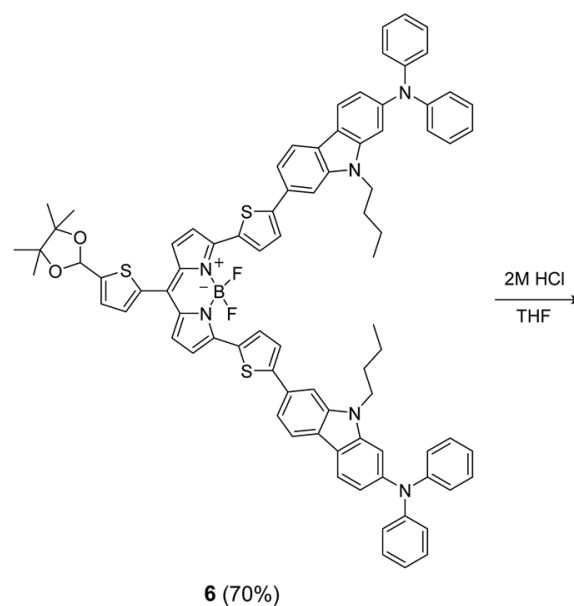

$6(70 \%)$

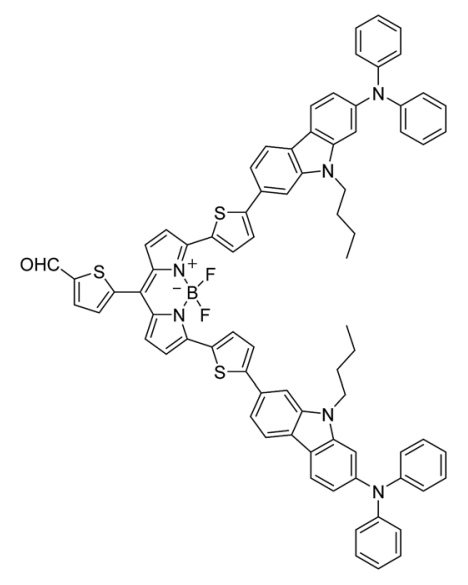

$7(99 \%)$

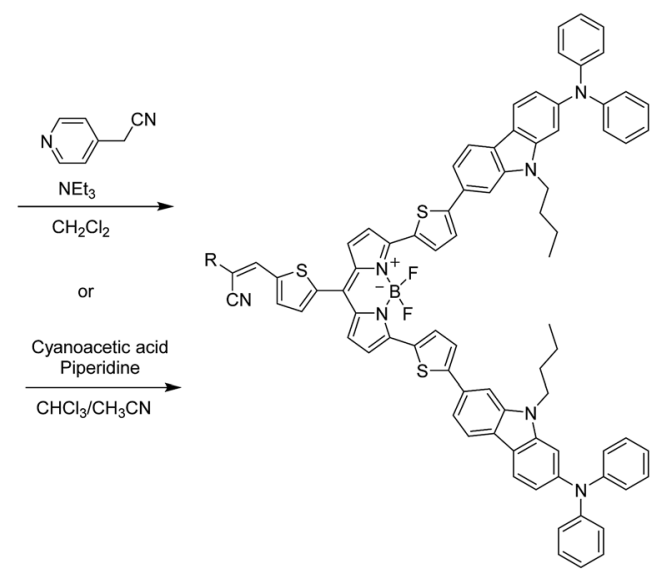

OMK-PY (40\%): R = N

OMK-CA $(61 \%):$ R = HOOC- 
(a)

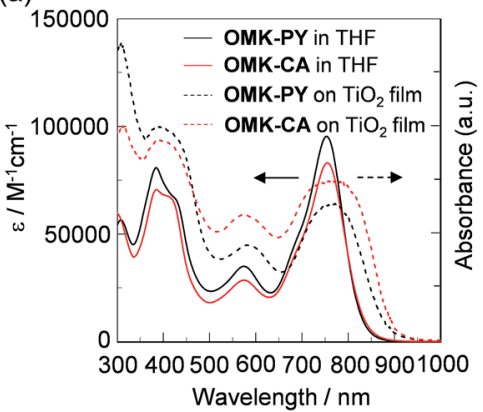

(b)

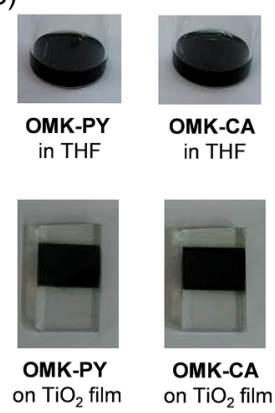

Fig. 2 (a) Photoabsorption spectra of OMK-PY and OMK-CA in THF and adsorbed on $\mathrm{TiO}_{2}$ film. (b) Photographs of the dyes in $\mathrm{THF}$ and adsorbed on $\mathrm{TiO}_{2}$ film.

was prepared by typical Knoevenagel condensation of the compound 7 with cyanoacetic acid in the presence of piperidine.

\section{Photophysical properties}

The photoabsorption spectra of OMK-PY and OMK-CA in THF and adsorbed on the $\mathrm{TiO}_{2}$ film are shown in Fig. 2a and their optical data are summarized in Table 1. The two dyes in THF show a strong and broad absorption band in the range of 600 to $800 \mathrm{~nm}$, which is assigned to the intramolecular charge-transfer (ICT) excitation from the electron donor moiety (two diphenylamine-thienylcarbazole moieties) through the BODIPY core to the electron acceptor moiety (2-(pyridin-4-yl)acrylonitrile moiety for OMK-PY and cyanoacetic acid group for OMK-CA, respectively). For OMK-PY the molar extinction coefficient $(\varepsilon)$ at the absorption peak wavelength $\left(\lambda_{\mathrm{abs}}=753 \mathrm{~nm}\right)$ is $95400 \mathrm{M}^{-1} \mathrm{~cm}^{-1}$, which is higher than that of OMK-CA $\left(\varepsilon=83100 \mathrm{M}^{-1} \mathrm{~cm}^{-1}\right.$ at $\lambda_{\text {abs }}=754 \mathrm{~nm}$ ). Moreover, for the two dyes a strong absorption peak at around $400 \mathrm{~nm}$ with the $\varepsilon$ value of $c a$. $70000-80000 \mathrm{M}^{-1}$ $\mathrm{cm}^{-1}$, which can be assigned to the ICT band due to the diphenylamine-thienylcarbazole moiety, was also observed. Interestingly, for the absorption spectra of OMK-PY and OMK-CA adsorbed on $\mathrm{TiO}_{2}$ film the longest wavelength absorption band in the range of 600 to $850 \mathrm{~nm}$ is significantly broadened, and the onset of the absorption band reached $900 \mathrm{~nm}$, compared with that in THF. As shown in Fig. 2b, the colors of the two dyes in THF are blackish green and the color of dye-adsorbed $\mathrm{TiO}_{2}$ film is almost black. Thus, this result indicates that the (D) $)_{2}-\pi-\mathrm{A}$ type BODIPY dyes possess a good LHE in the range of visible light to NIR light and good adsorption ability onto $\mathrm{TiO}_{2}$ electrode, that is,

OMK-PY and OMK-CA possess the NIR adsorption ability as well as the panchromatic adsorption ability.

\section{Electrochemical properties}

The electrochemical properties of OMK-PY and OMK-CA were determined by cyclic voltammetry (CV) in DMF containing $0.1 \mathrm{M}$ tetrabutylammonium perchlorate $\left(\mathrm{Bu}_{4} \mathrm{NClO}_{4}\right)$ (Fig. 3). The potentials were referenced to ferrocene/ferrocenium $\left(\mathrm{Fc} / \mathrm{Fc}^{+}\right)$as the internal reference. Two oxidation waves were observed at $0.34 \mathrm{~V}$ and $0.48 \mathrm{~V}$ for OMK-PY and $0.33 \mathrm{~V}$ and $0.48 \mathrm{~V}$ for OMK-CA, corresponding to the oxidations of the BODIPY core and the diphenylamino group, respectively. The corresponding reduction wave to the first oxidation wave appeared at $0.22 \mathrm{~V}$ for OMK-PY and $0.25 \mathrm{~V}$ for OMK-CA, respectively, whereas for the two dyes the corresponding reduction wave $(c a .0 .42 \mathrm{~V})$ to the second oxidation wave was not clearly observed. These results show that for the two dyes the first redox process is electrochemically reversible, but the second redox process is electrochemically irreversible. The HOMO energy levels of the two dyes were evaluated from the half-wave potential for oxidation $\left(E_{1 / 2}^{\mathrm{OX}}=0.28 \mathrm{~V}\right.$ for OMK-PY and $0.29 \mathrm{~V}$ for OMK-CA, respectively, Table 1). The HOMO energy level was $1.00 \mathrm{~V}$ for OMK-PY and 1.01 V for OMK-CA, respectively, versus the normal hydrogen electrode (NHE). Thus, the two dyes have comparable HOMO energy levels. This result shows that the HOMO energy levels of the two dyes are more positive than the $I_{3}{ }^{-}$/ $\Gamma$ redox potential $(0.4 \mathrm{~V})$, and thus this ensures an efficient regeneration of the oxidized dyes by electron transfer from the $\mathrm{I}_{3}{ }^{-}$/ $I$ redox couple in the electrolyte. The LUMO energy level was estimated from the $E_{1 / 2}^{\mathrm{ox}}$ and the onset of photoabsorption spectra (860 nm; $1.44 \mathrm{eV}$ for both OMK-PY and OMK-CA) in THF. The LUMO energy level was $-0.44 \mathrm{~V}$ for OMK-PY and $-0.43 \mathrm{~V}$ for OMKCA, respectively, and thus the two dyes have comparable LUMO energy levels. However, the LUMO energy levels of the two dyes are lower than the energy level $\left(E_{\mathrm{cb}}\right)$ of the conduction band (CB) of $\mathrm{TiO}_{2}$ electrode $(-0.5 \mathrm{~V})$. This suggests that the electron injection from the photoexcited dye to the $\mathrm{CB}$ of $\mathrm{TiO}_{2}$ electrode is thermodynamically difficult.

\section{Theoretical calculations}

To examine the electronic structures of OMK-PY and OMK-CA, the molecular orbitals of the two dyes were calculated using density functional theory (DFT) at the B3LYP/6-31G(d,p) level. ${ }^{28}$ As shown in Fig. 4, for the two dyes the HOMO and HOMO-1 are mostly localized on the BODIPY core containing the two diphenylaminethienylcarbazole moieties and the two diphenylamine-carbazole moieties, respectively. The LUMO is mostly localized on the

Table 1 Optical and electrochemical data, HOMO and LUMO energy levels, and DSSC performance parameters of OMK-PY and OMK-CA

\begin{tabular}{|c|c|c|c|c|c|c|c|c|c|}
\hline Dye & $\lambda_{\max }^{\mathrm{abs}} / \mathrm{nm}\left(\varepsilon^{a} / \mathbf{M}^{-1} \mathrm{~cm}^{-1}\right)$ & $E_{1 / 2}^{\mathrm{ox} b} / \mathrm{V}$ & $\mathrm{HOMO}^{c} / \mathrm{V}$ & $\mathrm{LUMO}^{c} / \mathrm{V}$ & Molecules ${ }^{d} / \mathrm{cm}^{-2}$ & $J_{\mathrm{sc}}{ }^{e} / \mathrm{mA} \mathrm{cm}^{-2}$ & $V_{\mathrm{oc}}{ }^{e} / \mathrm{mV}$ & $\mathrm{ff}^{e}$ & $\eta^{e}(\%)$ \\
\hline MK-PY & 385 (80 800), 574 (35 000), 753 (95 400) & 0.28 & 1.00 & -0.44 & $6.9 \times 10^{16}$ & 1.08 & 335 & 0.53 & 0.19 \\
\hline OMK-CA & 385 (70 600), $574(28500), 754(83100)$ & 0.29 & 1.01 & -0.43 & $1.0 \times 10^{17}$ & 0.68 & 319 & 0.51 & 0.11 \\
\hline
\end{tabular}

${ }^{a}$ In THF. ${ }^{b}$ Half-wave potentials versus $\mathrm{Fc} / \mathrm{Fc}^{+}$of oxidation $\left(E_{1 / 2}^{\mathrm{ox}}\right)$ for OMK-PY and OMK-CA were recorded in $\mathrm{DMF} / \mathrm{Bu}_{4} \mathrm{NClO}{ }_{4}(0.1 \mathrm{M})$ solution. ${ }^{c}$ Versus normal hydrogen electrode (NHE). ${ }^{d}$ Adsorption amount of dye molecules per unit area of the $\mathrm{TiO}_{2}$ electrode, when the $9 \mu \mathrm{m}$ thick TiO ${ }_{2}$ electrode was immersed into $0.1 \mathrm{mM}$ dye solution in THF. ${ }^{e}$ Under a simulated solar light (AM 1.5, $100 \mathrm{~mW} \mathrm{~cm}^{-2}$ ). 


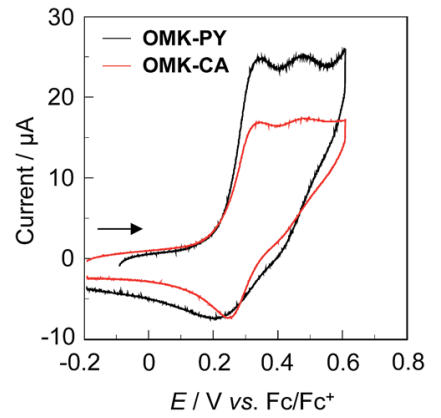

Fig. 3 Cyclic voltammograms of OMK-PY and OMK-CA in DMF containing $0.1 \mathrm{M} \mathrm{Bu}_{4} \mathrm{NClO}_{4}$. The arrow denotes the direction of the potential scan.

BODIPY core containing thiophene-2-(pyridin-4-yl)acrylonitrile moiety for OMK-PY and thiophene-cyanoacetic acid group for OMK-CA, respectively, and the LUMO+1 is mostly localized on thiophene-2-(pyridin-4-yl)acrylonitrile moiety for OMK-PY and thiophene-cyanoacetic acid group for OMK-CA, respectively. Accordingly, the DFT calculations reveal that for both OMK-PY and OMK-CA the dye excitations upon light irradiation induce a strong ICT from the electron donor moiety (two diphenylaminecarbazole moieties) through the BODIPY core to the electron acceptor moiety (2-(pyridin-4-yl)acrylonitrile moiety for OMK-PY and cyanoacetic acid group for OMK-CA, respectively).

\section{FT-IR spectra}

To elucidate the adsorption states of OMK-PY and OMK-CA on $\mathrm{TiO}_{2}$ nanoparticles, we measured the FTIR spectra of the dye powders and the dyes adsorbed on $\mathrm{TiO}_{2}$ film (Fig. 5). For the dye powder of OMK-PY the $\mathrm{C}=\mathrm{N}$ stretching band of the pyridyl group was observed at around $1590 \mathrm{~cm}^{-1}$. When OMK-PY was adsorbed on the $\mathrm{TiO}_{2}$ film, the $\mathrm{C}=\mathrm{N}$ stretching band was slightly shifted by $1 \mathrm{~cm}^{-1}$, to higher wavenumber compared with the dye powders, that is, the band can be assigned to the hydrogen-bonded pyridyl group to Brønsted acid sites on the $\mathrm{TiO}_{2}$ surface. ${ }^{18}$ For the dye powder of OMK-CA, the $\mathrm{C}=\mathrm{O}$ stretching band of the carboxyl group was observed at around $1690 \mathrm{~cm}^{-1}$. On the other hand, in the FTIR spectrum of OMK-CA adsorbed onto $\mathrm{TiO}_{2}$ film showed that the $\mathrm{C}=\mathrm{O}$ stretching bands of the carboxyl group disappeared completely; this indicates the formation of a bidentate bridging linkage between the carboxyl group of the dye and the Brønsted acid site on the $\mathrm{TiO}_{2}$ surface. Consequently, this result demonstrates that OMK-PY and OMKCA was adsorbed on the $\mathrm{TiO}_{2}$ film through the hydrogen bond and bidentate bridging linkage, respectively, at the Brønstedacidic sites on the $\mathrm{TiO}_{2}$ surface.

\section{Photovoltaic performances}

The DSSCs based on OMK-PY and OMK-CA were fabricated by using the dye-adsorbed $\mathrm{TiO}_{2}$ electrode $(9 \mu \mathrm{m})$, Pt-coated glass as a counter electrode, and an acetonitrile solution with iodine (0.05 M), lithium iodide $(0.1 \mathrm{M})$, and 1,2-dimethyl-3propylimidazolium iodide $(0.6 \mathrm{M})$ as the electrolyte. The $I-V$ characteristics were measured under simulated solar light (AM $1.5,100 \mathrm{~mW} \mathrm{~cm}^{-2}$ ). The IPCE spectra and the $I-V$ curves are shown in Fig. 6. The photovoltaic performance parameters (a short circuit photocurrent density $\left(J_{\mathrm{sc}}\right)$, an open-circuit photovoltage $\left(V_{\text {oc }}\right)$, a fill factor (ff) and a solar energy-to-electricity conversion yield $(\eta)$ ) are collected in Table 1 . The adsorption amount $\left(1.0 \times 10^{17}\right.$ molecules per $\left.\mathrm{cm}^{2}\right)$ of OMK-CA adsorbed on $\mathrm{TiO}_{2}$ electrode is larger than that of OMK-PY $\left(6.9 \times 10^{16}\right.$ molecules per $\mathrm{cm}^{2}$ ). The high adsorption ability of OMK-CA relative (a)

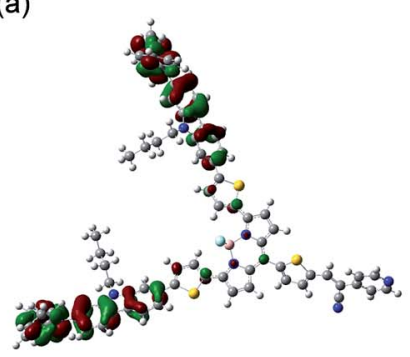

HOMO - 1

(b)

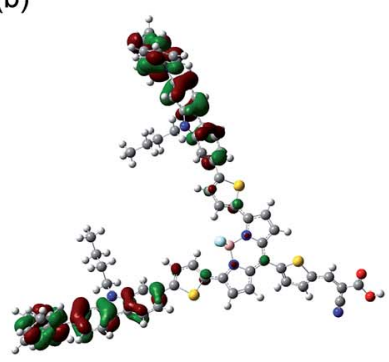

HOMO - 1

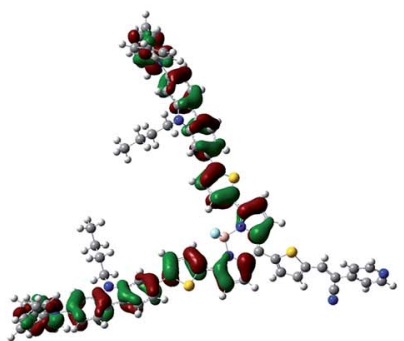

HOMO

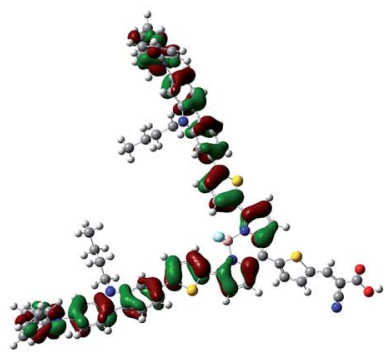

HOMO

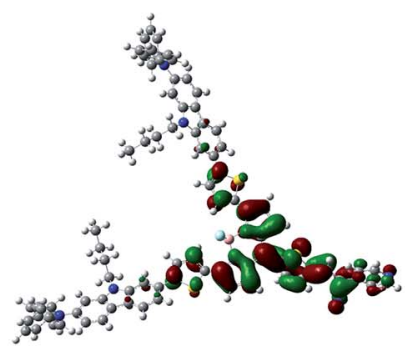

LUMO

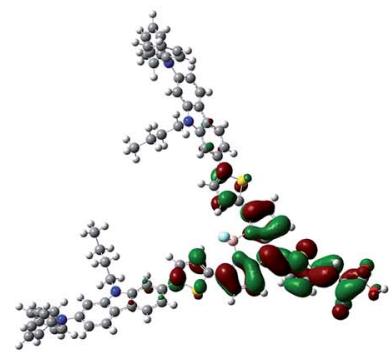

LUMO

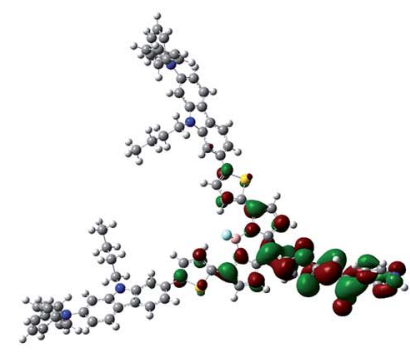

LUMO + 1

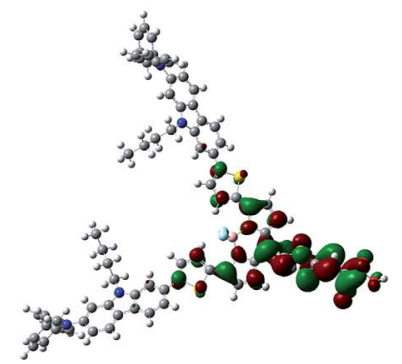

$\mathrm{LUMO}+1$

Fig. 4 HOMO-1, HOMO, LUMO and LUMO+1 of (a) OMK-PY and (b) OMK-CA derived from the DFT calculations at B3LYP/6-31G(d,p) level. 
(a)

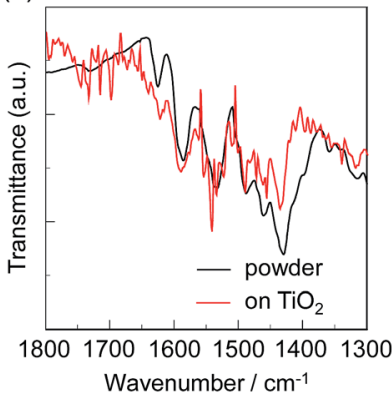

(b)

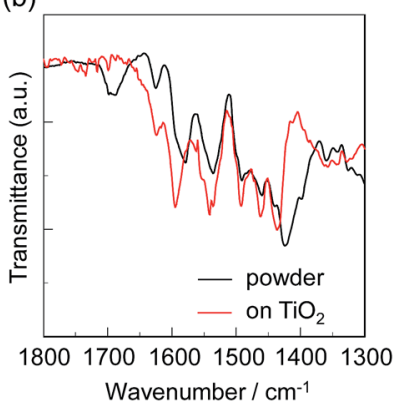

Fig. 5 FTIR spectra of the dye powder and the dye-adsorbed $\mathrm{TiO}_{2}$ film. (a) OMK-PY and (b) OMK-CA.

to OMK-PY is attributed to the formation of the bidentate bridging linkage between the carboxyl group of OMK-CA and the Brønsted acid sites on the $\mathrm{TiO}_{2}$ surface. The IPCE spectra showed that the maximum IPCE values of OMK-PY and OMK-CA are 13\% and $9 \%$, respectively. It is worth mentioning here that for the two dyes the IPCE value in the range of 600 to $800 \mathrm{~nm}$ is notably much lower than that at around $400 \mathrm{~nm}$, that is, the ICT band from the electron donor moiety through the BODIPY core to the electron acceptor moiety make little contribution to the IPCE spectra. The $I-V$ curves show that the $J_{\mathrm{sc}}$ and $\eta$ values are $1.08 \mathrm{~mA} \mathrm{~cm}{ }^{-2}$ and $0.19 \%$ for OMK-PY and $0.68 \mathrm{~mA} \mathrm{~cm}^{-2}$ and $0.11 \%$ for OMK-CA, respectively. Accordingly, the relatively low photovoltaic performances of OMK-PY and OMK-CA are due to the low LUMO level which makes it thermodynamically difficult for the photoexcited dye to inject the electron into the $\mathrm{CB}$ of $\mathrm{TiO}_{2}$ electrode. In addition, the $V_{\mathrm{oc}}$ value of BODIPY dye sensitizers is generally lower than that of the conventional organic dye sensitizers. ${ }^{23}$ It is assumed that the low $V_{\text {oc }}$ value $(c a .330 \mathrm{mV}$ ) for OMK-PY and OMK-CA is attributed to faster charge recombination between the injected electrons in the $\mathrm{CB}$ of $\mathrm{TiO}_{2}$ electrode and $I_{3}{ }^{-}$ions in the electrolyte, arising from the approach of $\mathrm{I}_{3}{ }^{-}$ions to the $\mathrm{TiO}_{2}$ surface due to the electrostatic interactions between the BODIPY core and $\mathrm{I}_{3}{ }^{-}$ions. Consequently, the low photovoltaic performances of DSSCs based on OMK-PY and OMK-CA are attributed to the low electron-injection efficiency due to the low LUMO level and the faster charge recombination due to the BODIPY core, leading to the low $J_{\mathrm{sc}}$ and $V_{\mathrm{oc}}$ values, respectively.
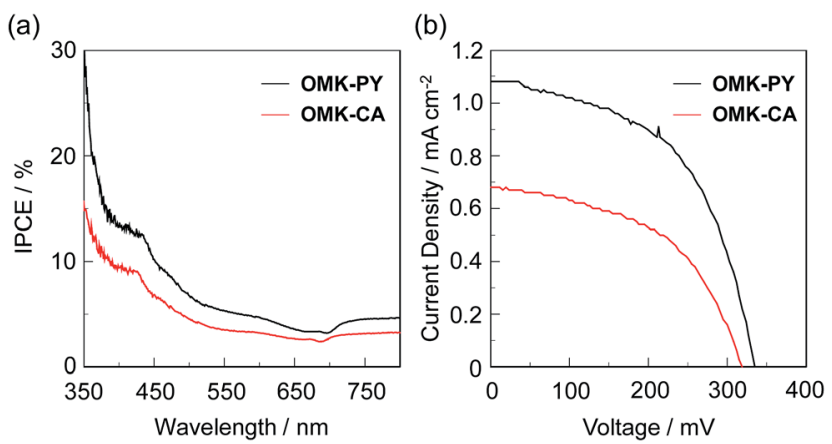

Fig. 6 (a) IPCE spectra and (b) I-V curves of DSSCs based on OMK-PY and OMK-CA.

\section{Conclusions}

To explore effective BODIPY dye sensitizers possessing a high LHE in the range of visible light to NIR light, we have designed and developed (D) ${ }_{2}-\pi$-A type BODIPY dyes OMK-PY and OMK-CA bearing pyridyl group and cyanoacrylic acid group, respectively, at the end of 8-positions on the BODIPY core, as an electronwithdrawing anchoring group to adsorb onto the $\mathrm{TiO}_{2}$ electrode and two diphenylamine-thienylcarbazole moieties as an electrondonating unit at the 3-and 5-positions on the BODIPY core. It was found that for the absorption spectra of OMK-PY and OMK-CA adsorbed on $\mathrm{TiO}_{2}$ film the two dyes show a strong and broad absorption band in the range of 600 to $850 \mathrm{~nm}$, and the onset of the absorption band reached $900 \mathrm{~nm}$, that is, OMK-PY and OMKCA possess the NIR adsorption ability as well as the panchromatic adsorption ability. Consequently, we demonstrate that (D) ${ }_{2}-\pi-\mathrm{A}$ BODIPY structure having two diphenylamine-thienylcarbazole moieties as strong electron-donating units at the 3- and 5-positions on the BODIPY core is an effective strategy to lead a high LHE in the range of visible light to NIR light, although the DSSCs based on $(\mathrm{D})_{2}-\pi$-A type BODIPY dyes that have been developed in this current stage showed low photovoltaic performances due to the low LUMO level.

\section{Experimental}

\section{General}

Melting points were measured with a Yanaco micro melting point apparatus MP model. IR spectra were recorded on a SHIMADZU IRAffinity-1 spectrometer by ATR method. Highresolution mass spectral data were acquired on a Thermo Fisher Scientific LTQ Orbitrap XL. ${ }^{1} \mathrm{H}$ NMR and ${ }^{13} \mathrm{C}$ NMR spectra were recorded on a Varian-400 $(400 \mathrm{MHz})$ or a Varian$500(500 \mathrm{MHz})$ FT NMR spectrometer. Absorption spectra were observed with a Shimadzu UV-3150 spectrophotometer. Cyclic voltammetry (CV) curves were recorded in $\mathrm{DMF} / \mathrm{Bu}_{4^{-}}$ $\mathrm{NClO}_{4}(0.1 \mathrm{M})$ solution with a three-electrode system consisting of $\mathrm{Ag} / \mathrm{Ag}^{+}$as reference electrode, Pt plate as working electrode, and Pt wire as counter electrode by using a AMETEK Versa STAT 4 potentiostat. The potentials were referenced to ferrocene/ ferrocenium $\left(\mathrm{Fc} / \mathrm{Fc}^{+}\right)$as the internal reference. The HOMO and LUMO energy levels of OMK-PY and OMK-CA were evaluated from the spectral analyses and the CV data. Thus, the HOMO energy level was evaluated from the $E_{1 / 2}^{o x}$. The LUMO energy level was estimated from the $E_{1 / 2}^{\mathrm{ox}}$ and the onset of photoabsorption spectra $(860 \mathrm{~nm} ; 1.44 \mathrm{eV}$ for both OMK-PY and OMK-CA) in THF, that is, the LUMO energy level was obtained through eq. $-\left[E_{0-0}-\mathrm{HOMO}\right]$, where $E_{0-0}$ transition energy is the onset of photoabsorption spectra corresponding to the energy gap between HOMO and LUMO.

\section{Synthesis}

2,2'-((5-(4,4,5,5-Tetramethyl-1,3-dioxolan-2-yl)thiophen-2-yl) methylene)bis(1H-pyrrole) (2). To a dichloromethane solution $(40 \mathrm{ml})$ of 1 (ref. 26$)(0.1 \mathrm{~g}, 0.42 \mathrm{mmol})$ and pyrrole $(0.06 \mathrm{ml}$, $0.88 \mathrm{mmol}$ ) under an argon atmosphere was added 
trifluoroacetic acid $(0.0005 \mathrm{ml})$ and stirred for $2 \mathrm{~h}$ at room temperature. The reaction mixture was diluted with water, and then the solution was extracted with dichloromethane. The dichloromethane extract was dried over $\mathrm{MgSO}_{4}$, filtrated, and concentrated. The residue was chromatographed on silica gel (dichloromethane-ethyl acetate $=9: 1$ as eluent) to give 2 ( $0.07 \mathrm{~g}$, yield $50 \%$ ) as a yellow viscous solid; IR (ATR): $\tilde{\nu}=3358$, 2976, 1670, $1553 \mathrm{~cm}^{-1} ;{ }^{1} \mathrm{H}$ NMR $\left(500 \mathrm{MHz}, \mathrm{CDCl}_{3}\right) \delta=1.29$ (d, $12 \mathrm{H}), 5.71(\mathrm{~s}, 1 \mathrm{H}), 6.04(\mathrm{br}, 2 \mathrm{H}), 6.12(\mathrm{~s}, 1 \mathrm{H}), 6.14-6.16(\mathrm{~m}, 2 \mathrm{H})$, 6.69-6.70 (m, 2H), $6.74(\mathrm{~d}, J=3.6 \mathrm{~Hz}, 1 \mathrm{H}), 7.00(\mathrm{~d}, J=3.6 \mathrm{~Hz}$, $1 \mathrm{H}) \mathrm{ppm} ;{ }^{13} \mathrm{C}$ NMR $\left(125 \mathrm{MHz}, \mathrm{CDCl}_{3}\right) \delta=22.22,24.54,39.54$, 83.17 , 96.86, 107.22, 108.59, 117.54, 125.30, 126.43, 131.74, 142.59, 146.80 ppm; HRMS (ESI): $m / z(\%):\left[\mathrm{M}+\mathrm{H}^{+}\right]$calcd for $\mathrm{C}_{20} \mathrm{H}_{25} \mathrm{~N}_{2} \mathrm{O}_{2} \mathrm{~S}$, 357.16313; found 357.16336.

(E)-2-Chloro-5-((5-chloro-2H-pyrrol-2-ylidene)(5-(4,4,5,5-tetramethyl-1,3-dioxolan-2-yl)thiophen-2-yl)methyl)-1 $\boldsymbol{H}$-pyrrole (3). To compound $2(2.68 \mathrm{~g}, 7.52 \mathrm{mmol})$ under an argon atmosphere was added THF $(40 \mathrm{ml})$ and then stirred at $-75{ }^{\circ} \mathrm{C}$. Next, a solution of $\mathrm{N}$-chlorosuccinimide $(2.01 \mathrm{~g}, 15.1 \mathrm{mmol})$ in THF $(30 \mathrm{ml})$ was added dropwise and the solution was stirred at $-75{ }^{\circ} \mathrm{C}$ for $1 \mathrm{~h}$ and then at room temperature for $2 \mathrm{~h}$. After concentrating under reduced pressure, the resulting residue was dissolved in dichloromethane and washed with water. To the dichloromethane extract $(150 \mathrm{ml})$ was added DDQ $(1.71 \mathrm{~g}, 7.52$ $\mathrm{mmol}$ ) and the solution was stirred at room temperature for $2 \mathrm{~h}$. After concentrating under reduced pressure, the residue was chromatographed on silica gel (dichloromethane as eluent) to give 3 (1.54 g, yield 49\%) as a reddish brown solid; mp 89-91 ${ }^{\circ} \mathrm{C}$; IR (ATR): $\tilde{\nu}=2967,1560,1420 \mathrm{~cm}^{-1} ;{ }^{1} \mathrm{H}$ NMR (500 MHz, $\mathrm{CDCl}_{3}$ ) $\delta=1.33(\mathrm{~d}, 12 \mathrm{H}), 6.21(\mathrm{~s}, 1 \mathrm{H}), 6.29(\mathrm{~d}, J=4.3 \mathrm{~Hz}, 2 \mathrm{H}), 6.90(\mathrm{~d}, J=$ $4.3 \mathrm{~Hz}, 2 \mathrm{H}), 7.19$ (br, 2H) ppm; ${ }^{13} \mathrm{C}$ NMR (125 MHz, $\left.\mathrm{CDCl}_{3}\right) \delta=$ 22.20, 24.40, 83.57, 96.58, 117.18, 126.28, 130.33, 131.53, 132.40, 136.98, 138.44, 142.12, 147.64 ppm; HRMS (ESI): $m / z$ (\%): [M + $\left.\mathrm{H}^{+}\right]$calcd for $\mathrm{C}_{20} \mathrm{H}_{21} \mathrm{~N}_{2} \mathrm{O}_{2} \mathrm{Cl}_{2} \mathrm{~S}, 423.06953$; found 423.06921 .

3,7-Dichloro-5,5-difluoro-10-(5-(4,4,5,5-tetramethyl-1,3-dioxolan-2-yl)thiophen-2-yl)-5H-dipyrrolo[1,2-c:2 $\left.2^{\prime}, 1^{\prime}-f\right][1,3,2]$ diazaborinine (4). To a compound $3(1.5 \mathrm{~g}, 3.55 \mathrm{mmol})$ under an argon atmosphere was added dichloromethane $(100 \mathrm{ml})$ and triethylamine $(4.72 \mathrm{ml}, 35.5 \mathrm{mmol})$ and stirred for $30 \mathrm{~min}$ at room temperature. Next, $\mathrm{BF}_{3}-\mathrm{OEt}_{2}(6.25 \mathrm{ml}, 53.3 \mathrm{mmol})$ was added dropwise and the solution was stirred at room temperature for $12 \mathrm{~h}$. The reaction mixture was washed with water and extracted with dichloromethane. The dichloromethane extract was dried over $\mathrm{MgSO}_{4}$, filtrated, and concentrated. The residue was chromatographed on silica gel (dichloromethane-hexane = $1: 2$ as eluent) to give $4(1.11 \mathrm{~g}$, yield $67 \%)$ as a dark red solid; mp 185-187 ${ }^{\circ} \mathrm{C}$; IR (ATR): $\tilde{v}=2982,1545,1381 \mathrm{~cm}^{-1} ;{ }^{1} \mathrm{H}$ NMR $\left(500 \mathrm{MHz}\right.$, acetone- $\left.\mathrm{d}_{6}\right) \delta=1.31(\mathrm{~s}, 12 \mathrm{H}), 6.26(\mathrm{~s}, 1 \mathrm{H}), 6.71(\mathrm{~d}, J=$ $4.4 \mathrm{~Hz}, 2 \mathrm{H}), 7.42(\mathrm{~d}, J=3.8 \mathrm{~Hz}, 1 \mathrm{H}), 7.43(\mathrm{~d}, J=4.4 \mathrm{~Hz}, 2 \mathrm{H}), 7.65$ $(\mathrm{d}, J=3.8 \mathrm{~Hz}, 1 \mathrm{H}) \mathrm{ppm} ;{ }^{13} \mathrm{C}$ NMR $\left(125 \mathrm{MHz}\right.$, acetone- $\left.\mathrm{d}_{6}\right) \delta=$ 22.34, 24.51, 84.17, 96.90, 119.96, 128.16, 133.17, 133.34, 133.95, 134.73, 144.76, 152.63, 153.81 ppm; HRMS (ESI): $m / z$ (\%): [M + $\left.\mathrm{Na}^{+}\right]$calcd for $\mathrm{C}_{20} \mathrm{H}_{19} \mathrm{~N}_{2} \mathrm{O}_{2} \mathrm{BF}_{2} \mathrm{Cl}_{2} \mathrm{SNa}, 493.04976$; found 493.04974 .

7,7'-((5,5-Difluoro-10-(5-(4,4,5,5-tetramethyl-1,3-dioxolan-2-yl)thiophen-2-yl)-5H-dipyrrolo[1,2-c:2' $\left.2^{\prime}-f\right][1,3,2]$ diazaborinine-3,7diyl)bis(thiophene-5,2-diyl))bis(9-butyl- $N, N$-diphenyl-9H-carbazol- 2-amine) (6). A solution of 4 (1.0 g, $2.13 \mathrm{mmol}$ ), 5 (ref. $18 \mathrm{~g}$ ) (2.71 g, $4.25 \mathrm{mmol})$, and $\mathrm{Pd}\left(\mathrm{PPh}_{3}\right)_{4}(2.94 \mathrm{~g}, 2.54 \mathrm{mmol})$ in toluene $(270 \mathrm{ml})$ was stirred for $12 \mathrm{~h}$ at $110{ }^{\circ} \mathrm{C}$ under an argon atmosphere. After concentrating under reduced pressure, the resulting residue was dissolved in dichloromethane and washed with water. The dichloromethane extract was dried over $\mathrm{MgSO}_{4}$, filtrated, and concentrated. The residue was chromatographed on silica gel (chloroform-hexane =1:2 as eluent) to give 6 (1.99 g, yield 70\%) as a blackish green solid; mp 176-177 ${ }^{\circ} \mathrm{C}$; IR (ATR): $\tilde{\nu}=2955$, 1591, $1431 \mathrm{~cm}^{-1} ;{ }^{1} \mathrm{H}$ NMR (400 MHz, acetone- $\left.\mathrm{d}_{6}\right) \delta=0.88(\mathrm{t}, J=$ $7.4 \mathrm{~Hz}, 6 \mathrm{H}), 1.32-1.34(\mathrm{~m}, 16 \mathrm{H}), 1.77-1.84(\mathrm{~m}, 4 \mathrm{H}), 4.37(\mathrm{t}, J=$ $7.0 \mathrm{~Hz}, 4 \mathrm{H}), 6.29$ (s, 1H), $6.94(\mathrm{dd}, J=1.8$ and $8.4 \mathrm{~Hz}, 2 \mathrm{H}), 7.04-$ $7.08(\mathrm{~m}, 4 \mathrm{H}), 7.13-7.14(\mathrm{~m}, 10 \mathrm{H}), 7.23$ (d, $J=1.8 \mathrm{~Hz}, 2 \mathrm{H}), 7.30-$ $7.34(\mathrm{~m}, 10 \mathrm{H}), 7.40(\mathrm{~d}, J=3.8 \mathrm{~Hz}, 1 \mathrm{H}), 7.55(\mathrm{~d}, J=3.7 \mathrm{~Hz}, 1 \mathrm{H}), 7.64$ $(\mathrm{dd}, J=1.5$ and $8.1 \mathrm{~Hz}, 2 \mathrm{H}), 7.76(\mathrm{~d}, J=4.1 \mathrm{~Hz}, 2 \mathrm{H}), 7.95(\mathrm{~d}, J=$ $1.2 \mathrm{~Hz}, 2 \mathrm{H}), 8.06$ (d, $J=8.4 \mathrm{~Hz}, 2 \mathrm{H}), 8.15$ (d, $J=8.0 \mathrm{~Hz}, 2 \mathrm{H}), 8.31$ $(\mathrm{d}, J=4.1 \mathrm{~Hz}, 2 \mathrm{H}) \mathrm{ppm} ;{ }^{13} \mathrm{C}$ NMR $\left(125 \mathrm{MHz}\right.$, acetone-d $\left.\mathrm{d}_{6}\right) \delta=$ $14.18,21.02,22.38$, 24.60, 31.84, 43.07, 84.02, 97.12, 105.79, $106.95,117.90,118.44,119.25,121.22,121.60,122.04,123.65$, $124.26,124.88,126.15,126.47,127.67,130.18,130.79,131.21$, $132.77,133.72,133.91,135.69,137.40,142.26,143.43,147.74$, 149.12, 150.10, 150.32, 150.98 ppm; HRMS (ESI): $m / z$ (\%): [M + $\left.\mathrm{Na}^{+}\right]$calcd for $\mathrm{C}_{84} \mathrm{H}_{73} \mathrm{~N}_{6} \mathrm{O}_{2} \mathrm{BF}_{2} \mathrm{~S}_{3} \mathrm{Na}, 1365.49105$; found 1365.49304.

5-(3,7-Bis(5-(9-butyl-7-(diphenylamino)-9H-carbazol-2-yl)thiophen-2-yl)-5,5-difluoro-5H-dipyrrolo[1,2-c:2', $\left.1^{\prime}-f\right][1,3,2]$ diazaborinin-10yl)thiophene-2-carbaldehyde (7). To a solution of 6 $(1.85 \mathrm{~g}, 1.38 \mathrm{mmol})$ in THF $(20 \mathrm{ml})$ was added $2 \mathrm{~N} \mathrm{HCl}(13.8 \mathrm{ml})$ and refluxed for $12 \mathrm{~h}$. The reaction mixture was washed with water and extracted with dichloromethane. The dichloromethane extract was dried over $\mathrm{MgSO}_{4}$, filtrated, and concentrated. The residue was chromatographed on silica gel (dichloromethane-hexane $=1: 1$ as eluent) to give $7(1.71 \mathrm{~g}$, yield 99\%) as a dark green solid; mp 171-172 ${ }^{\circ} \mathrm{C}$; IR (ATR): $\tilde{\nu}=$ 2953, 1665, $1585 \mathrm{~cm}^{-1}$; ${ }^{1} \mathrm{H}$ NMR (500 MHz, acetone-d $\left.{ }_{6}\right) \delta=0.88$ $(\mathrm{t}, J=7.4 \mathrm{~Hz}, 6 \mathrm{H}), 1.29-1.36(\mathrm{~m}, 4 \mathrm{H}), 1.78-1.83(\mathrm{~m}, 4 \mathrm{H}), 4.37(\mathrm{t}, J$ $=6.9 \mathrm{~Hz}, 4 \mathrm{H}), 6.94(\mathrm{dd}, J=1.9$ and $8.4 \mathrm{~Hz}, 2 \mathrm{H}), 7.05-7.07(\mathrm{~m}$, $4 \mathrm{H}), 7.13-7.15(\mathrm{~m}, 8 \mathrm{H}), 7.17$ (d, $J=4.8 \mathrm{~Hz}, 2 \mathrm{H}), 7.23$ (d, $J=$ $1.8 \mathrm{~Hz}, 2 \mathrm{H}), 7.28-7.33(\mathrm{~m}, 10 \mathrm{H}), 7.65(\mathrm{dd}, J=1.5$ and $8.1 \mathrm{~Hz}, 2 \mathrm{H})$, $7.78(\mathrm{~d}, J=4.0 \mathrm{~Hz}, 2 \mathrm{H}), 7.81$ (d, $J=3.5 \mathrm{~Hz}, 1 \mathrm{H}), 7.96$ (d, $J=$ $1.0 \mathrm{~Hz}, 2 \mathrm{H}), 8.07$ (d, $J=8.4 \mathrm{~Hz}, 2 \mathrm{H}), 8.15$ (d, $J=8.1 \mathrm{~Hz}, 2 \mathrm{H}), 8.18$ $(\mathrm{d}, J=3.5 \mathrm{~Hz}, 1 \mathrm{H}), 8.35$ (d, $J=3.8 \mathrm{~Hz}, 2 \mathrm{H}), 10.12$ (s, -CHO) ppm; ${ }^{13} \mathrm{C}$ NMR (125 MHz, acetone-d $\left.\mathrm{d}_{6}\right) \delta=14.18,21.02,31.85,43.08$, $105.77,107.01,117.91,118.46,119.21,121.24,122.07,123.67$, $124.37,124.89,126.29,130.18,130.56,131.11,133.53,133.82$, 137.44, 137.61, 142.25, 143.46, 143.57, 147.81, 149.10, 150.99, 151.65, $184.42 \mathrm{ppm}$ (four aromatic carbon signals were not observed owing to overlapping resonances); HRMS (ESI): $\mathrm{m} / \mathrm{z}$ (\%): $\left[\mathrm{M}+\mathrm{H}^{+}\right]$calcd for $\mathrm{C}_{76} \mathrm{H}_{62} \mathrm{~N}_{6} \mathrm{OBF}_{2} \mathrm{~S}_{3}, 1243.42029$; found 1243.42139.

3-(5-(3,7-Bis(5-(9-butyl-7-(diphenylamino)-9H-carbazol-2-yl) thiophen-2-yl)-5,5-difluoro-5H-4dipyrrolo[1,2-c:2' $\left.\mathbf{1}^{\prime}-f\right][1,3,2]$ diazaborinin-10-yl)thiophen-2-yl)-2-(pyridin-4-yl)acrylonitrile (OMK-PY). To a solution of 4-pyridylacetonitrile hydrochloride $(0.05 \mathrm{~g}, 0.322 \mathrm{mmol})$ in dichloromethane $(3 \mathrm{ml})$ was added triethylamine $(0.21 \mathrm{ml}, 1.61 \mathrm{mmol})$ and stirred for 
$20 \mathrm{~min}$ at $0{ }^{\circ} \mathrm{C}$. Next, $7(0.4 \mathrm{~g}, 0.322 \mathrm{mmol})$ was added and the solution was stirred at room temperature for 5 days. The reaction mixture was washed with water and extracted with dichloromethane. The dichloromethane extract was dried over $\mathrm{MgSO}_{4}$, filtrated, and concentrated. The residue was chromatographed on silica gel (dichloromethane and then ethyl acetate as eluent) to give OMK-PY (0.171 g, yield $40 \%)$ as a dark green solid; mp 169-170 ${ }^{\circ} \mathrm{C}$; IR (ATR): $\tilde{\nu}=2924,1585$, $1429 \mathrm{~cm}^{-1} ;{ }^{1} \mathrm{H}$ NMR $\left(500 \mathrm{MHz}\right.$, acetone- $\left.\mathrm{d}_{6}\right) \delta=0.88(\mathrm{t}, J=$ $7.4 \mathrm{~Hz}, 6 \mathrm{H}), 1.30-1.35(\mathrm{~m}, 4 \mathrm{H}), 1.79-1.82(\mathrm{~m}, 4 \mathrm{H}), 4.37(\mathrm{t}, J=$ $6.6 \mathrm{~Hz}, 4 \mathrm{H}), 6.94(\mathrm{~d}, J=8.3 \mathrm{~Hz}, 2 \mathrm{H}), 7.04-7.07(\mathrm{~m}, 4 \mathrm{H}), 7.13-$ $7.14(\mathrm{~m}, 8 \mathrm{H}), 7.18(\mathrm{br}, 2 \mathrm{H}), 7.23(\mathrm{~s}, 2 \mathrm{H}), 7.30-7.33(\mathrm{~m}, 10 \mathrm{H})$, $7.64(\mathrm{~d}, J=8.9 \mathrm{~Hz}, 2 \mathrm{H}), 7.75-7.78(\mathrm{~m}, 5 \mathrm{H}), 7.96(\mathrm{~s}, 2 \mathrm{H}), 8.05-$ $8.07(\mathrm{~m}, 3 \mathrm{H}), 8.15(\mathrm{~d}, J=8.9 \mathrm{~Hz}, 2 \mathrm{H}), 8.34(\mathrm{br}, 2 \mathrm{H}), 8.58(\mathrm{~s}$, $1 \mathrm{H}), 8.73(\mathrm{~d}, J=5.9 \mathrm{~Hz}, 2 \mathrm{H}) \mathrm{ppm} ;{ }^{13} \mathrm{C}$ NMR $(125 \mathrm{MHz}$, acetone- $\left.\mathrm{d}_{6}\right) \delta=14.18,21.02,31.85,43.09$, 105.78, 107.01, $117.49,117.74,117.92,118.46,119.22,120.53,121.25,122.07$, 123.67, 124.36, 124.89, 125.99, 126.28, 129.64, 130.18, 130.51, 131.15, 133.63, 133.77, 134.27, 137.93, 142.26, 143.46, 147.80, 149.11, 151.65 ppm (seven aromatic carbon signals were not observed owing to overlapping resonances); HRMS (ESI): $\mathrm{m} / \mathrm{z}$ (\%): $\left[\mathrm{M}+\mathrm{H}^{+}\right]$calcd for $\mathrm{C}_{85} \mathrm{H}_{66} \mathrm{~N}_{8} \mathrm{BF}_{2} \mathrm{~S}_{3}, 1343.46282$; found 1343.46300 .

3-(5-(3,7-Bis(5-(9-butyl-7-(diphenylamino)-9H-carbazol-2-yl) thiophen-2-yl)-5,5-difluoro-5H-dipyrrolo[1,2-c:2', $\left.1^{\prime}-f\right][1,3,2]$ diazaborinin-10-yl)thiophen-2-yl)-2-cyanoacrylic acid (OMK-CA). A solution of 7 ( $0.4 \mathrm{~g}, 0.322 \mathrm{mmol})$, cyanoacetic acid $(0.11 \mathrm{~g}, 0.644 \mathrm{mmol})$ and piperidine (0.032 ml, $0.322 \mathrm{mmol})$ in chloroform/acetonitrile $(1: 1$, $65 \mathrm{ml}$ ) was refluxed for $22 \mathrm{~h}$. After concentrating under reduced pressure, the resulting residue was chromatographed on silica gel (ethyl acetate and then ethyl acetate containing 5\% acetic acid as eluent) to give the mixture OMK-CA and unreacted cyanoacetic acid. The mixture was dissolved in dichloromethane and washed with water. The dichloromethane extract was dried over $\mathrm{MgSO}_{4}$, filtrated, and concentrated to give OMK-CA $(0.256 \mathrm{~g}$, yield $61 \%)$ as a dark green solid; mp 176-179 ${ }^{\circ} \mathrm{C}$; IR (ATR): $\tilde{\nu}=2922,1688,1578$, $1424 \mathrm{~cm}^{-1} ;{ }^{1} \mathrm{H}$ NMR (500 MHz, DMSO-d $\left.{ }_{6}\right) \delta=0.79(\mathrm{t}, J=7.5 \mathrm{~Hz}$, $6 \mathrm{H}), 1.17-1.23(\mathrm{~m}, 4 \mathrm{H}), 1.62-1.68(\mathrm{~m}, 4 \mathrm{H}), 4.29(\mathrm{t}, J=6.8 \mathrm{~Hz}, 4 \mathrm{H})$, $6.87(\mathrm{dd}, J=1.6$ and $8.5 \mathrm{~Hz}, 2 \mathrm{H}), 7.03-7.08(\mathrm{~m}, 12 \mathrm{H}), 7.15(\mathrm{~d}, J=$ $1.5 \mathrm{~Hz}, 2 \mathrm{H}), 7.26(\mathrm{~d}, J=4.5 \mathrm{~Hz}, 2 \mathrm{H}), 7.29-7.33(\mathrm{~m}, 10 \mathrm{H}), 7.60(\mathrm{~d}, J=$ $9.1 \mathrm{~Hz}, 2 \mathrm{H}), 7.84(\mathrm{~d}, J=3.9 \mathrm{~Hz}, 1 \mathrm{H}), 7.90(\mathrm{~d}, J=4.1 \mathrm{~Hz}, 2 \mathrm{H}), 7.95(\mathrm{~s}$, $2 \mathrm{H}), 8.07(\mathrm{~d}, J=8.5 \mathrm{~Hz}, 2 \mathrm{H}), 8.13-8.15(\mathrm{~m}, 3 \mathrm{H}), 8.24(\mathrm{~d}, J=4.2 \mathrm{~Hz}$, $2 \mathrm{H}), 8.58$ (br, $-\mathrm{COOH}$ ) ppm; unfortunately, it was difficult to obtain the ${ }^{13} \mathrm{C}$ NMR spectrum of OMK-CA because of its poor solubility in deuterated solvent; HRMS (ESI): $m / z(\%)$ : $\left[\mathrm{M}^{+}\right]$calcd for $\mathrm{C}_{81} \mathrm{H}_{62^{-}}$ $\mathrm{N}_{7} \mathrm{O}_{2} \mathrm{BF}_{2} \mathrm{~S}_{3}, 1309.41827$; found 1309.42188.

\section{Preparation of DSSCs}

The $\mathrm{TiO}_{2}$ paste (JGC Catalysts and Chemicals Ltd., PST-18NR) was deposited on a fluorine-doped-tin-oxide (FTO) substrate by doctor-blading, and sintered for $50 \mathrm{~min}$ at $450{ }^{\circ} \mathrm{C}$. The $9 \mu \mathrm{m}$ thick $\mathrm{TiO}_{2}$ electrode was immersed into $0.1 \mathrm{mM}$ dye solution in THF for 15 hours enough to adsorb the dye sensitizers (OMK-PY and OMK-CA). The DSSCs were fabricated by using the $\mathrm{TiO}_{2}$ electrode $\left(0.5 \times 0.5 \mathrm{~cm}^{2}\right.$ in photoactive area) thus prepared, Ptcoated glass as a counter electrode, and a solution of $0.05 \mathrm{M}$ iodine, 0.1 M lithium iodide, and $0.6 \mathrm{M}$ 1,2-dimethyl-3propylimidazolium iodide in acetonitrile as electrolyte. The photocurrent-voltage characteristics were measured using a potentiostat under a simulated solar light (AM 1.5, $100 \mathrm{~mW}$ $\mathrm{cm}^{-2}$ ). IPCE spectra were measured under monochromatic irradiation with a tungsten-halogen lamp and a monochromator. The amount of dye molecules adsorbed on $\mathrm{TiO}_{2}$ film was determined form the calibration curve by absorption spectral measurement of the concentration change of the dye solution before and after adsorption. The quantification of dye was made based on the molar extinction coefficient for $\lambda_{\max }^{\text {abs }}$ of dye in the above solution. Absorption spectra of the dyes adsorbed on $\mathrm{TiO}_{2}$ film $(3 \mu \mathrm{m})$ were recorded on the dyesadsorbed $\mathrm{TiO}_{2}$ film in the transmission mode with a calibrated integrating sphere system.

\section{Acknowledgements}

This work was supported by Grants-in-Aid for Scientific Research (B) from the Japan Society for the Promotion of Science (JSPS) KAKENHI Grant Number 15H03859, by Matching Planner Program (MP27115659061) from Japan Science and Technology Agency (JST) and by Yazaki Memorial Foundation for Science and Technology.

\section{Notes and references}

1 A. Mishra, M. K. R. Fischer and P. Bäuerle, Angew. Chem., Int. Ed., 2009, 48, 2474.

2 (a) Y. Ooyama and Y. Harima, Eur. J. Org. Chem., 2009, 18, 2903; (b) Y. Ooyama and Y. Harima, ChemPhysChem, 2012, 13, 4032 .

3 (a) Z. Ning and H. Tian, Chem. Commun., 2009, 5483; (b) Z. Ning, Y. Fu and H. Tian, Energy Environ. Sci., 2010, 3, 1170.

4 A. Hagfeldt, G. Boschloo, L. Sun, L. Kloo and H. Pettersson, Chem. Rev., 2010, 110, 6595.

5 N. Manfredi, B. Cecconi and A. Abbotto, Eur. J. Org. Chem., 2014, 7069.

6 L. Zhang and J. M. Cole, ACS Appl. Mater. Interfaces, 2015, 7, 3427.

7 C.-P. Lee, R. Y.-Y. Lin, L.-Y. Lin, C.-T. Li, T.-C. Chu, S.-S. Sun, J. T. Lin and K.-C. Ho, RSC Adv., 2015, 5, 23810.

8 B. Pashaei, H. Shahroosvand, M. Graetzel and M. K. Nazeeruddin, Chem. Rev., 2016, 116, 9485.

9 B. O'Regan and M. Grätzel, Nature, 1991, 353, 737.

10 (a) H. Imahori, T. Umeyama and S. Ito, Acc. Chem. Res., 2009, 42, 1809; (b) L.-L. Li and E. W.-G. Diau, Chem. Soc. Rev., 2013, 42, 291; (c) K. Ladomenou, T. N. Kitsopoulos, G. D. Sharma and A. G. Coutsolelos, RSC Adv., 2014, 4, 21379; (d) T. Higashino and H. Imahori, Dalton Trans., 2015, 44, 448.

11 (a) T. Bessho, S. M. Zakeeruddin, C.-Y. Yeh, E. W.-G. Diau and M. Grätzel, Angew. Chem., Int. Ed., 2010, 49, 6646; (b) A. Yella, H.-W. Lee, H. N. Tsao, C. Yi, A. K. Chandiran, M. K. Nazeeruddin, E. W.-G. Diau, C.-Y. Yeh, S. M. Zakeeruddin and M. Grätzel, Science, 2011, 334, 629; (c) S. Mathew, A. Yella, P. Gao, R. Humphry-Baker, B. F. E. Curchod, N. Ashari-Astani, I. Tavernelli, 
U. Rothlisberger, M. K. Nazeeruddin and M. Grätzel, Nat. Chem., 2014, 6, 242; (d) A. Yella, C.-L. Mai, S. M. Zakeeruddin, S.-N. Chang, C.-H. Hsieh, C.-Y. Yeh and M. Grätzel, Angew. Chem., Int. Ed., 2014, 53, 2973; (e) T. Higashino, Y. Fujimori, K. Sugiura, Y. Tsuji, S. Ito and H. Imahori, Angew. Chem., Int. Ed., 2015, 54, 9052; (f) J. P. Hill, Angew. Chem., Int. Ed., 2016, 55, 2976; $(g)$ F. Lodermeyer, R. D. Costa, J. Malig, N. Jux and D. M. Guldi, Chem.-Eur. J., 2016, 22, 7851; (h) G. Copley, D. Hwang, D. Kim and A. Osuka, Angew. Chem., Int. Ed., 2016, 55, 10287.

12 (a) T. Zhang, X. Qian, P. Zhang, Y.-Z. Zhu and J.-Y. Zheng, Chem. Commun., 2015, 51, 3782; (b) Y. Xie, Y. Tang, W. Wu, Y. Wang, J. Liu, X. Li, H. Tian and W.-H. Zhu, J. Am. Chem. Soc., 2015, 137, 14055; (c) K. Sirithip, N. Prachumrak, R. Rattanawan, T. Keawin, T. Sudyoadsuk, S. Namuangruk, S. Jungsuttiwong and V. Promarak, Chem.-Asian J., 2015, 10, 882; (d) S. Mathew, N. A. Astani, B. F. E. Curchod, J. H. Delcamp, M. Marszalek, J. Frey, U. Rothlisberger, M. K. Nazeeruddina and M. Grätzel, J. Mater. Chem. A, 2016, 4, 2332; (e) L. Zeininger, F. Lodermeyer, R. D. Costa, D. M. Guldi and A. Hirsch, Chem. Commun., 2016, 52, 8842; (f) J. Luo, J. Zhang, K.-W. Huang, Q. Qi, S. Dong, J. Zhang, P. Wang and J. Wu, J. Mater. Chem. A, 2016, 4, 8428; $(g)$ C. Li, L. Luo, D. Wu, R. Jiang, J. Lan, R. Wang, L. Huang, S. Yang and J. You, J. Mater. Chem. A, 2016, 4, 11829; (h) Y.-C. Liu, H.-H. Chou, F.-Y. Ho, H.-J. Wei, T.-C. Wei and C.-Y. Yeh, J. Mater. Chem. A, 2016, 4, 11878.

13 (a) J.-J. Cid, J.-H. Yum, S.-R. Jang, M. K. Nazeeruddin, E. Martínez-Ferrero, E. Palomares, J. Ko, M. Grätzel and T. Torres, Angew. Chem., Int. Ed., 2007, 46, 8358; (b) M. Kimura, H. Nomoto, N. Masaki and S. Mori, Angew. Chem., Int. Ed., 2012, 51, 4371; (c) M.-E. Ragoussi, J.-J. Cid, J.-H. Yum, G. De La Torre, D. D. Censo, M. Grätzel, M. K. Nazeeruddin and T. Torres, Angew. Chem., Int. Ed., 2012, 51, 4375; (d) L. Yu, K. Fan, T. Duan, X. Chen, R. Li and T. Peng, ACS Sustainable Chem. Eng., 2014, 2, 718; (e) T. Ikeuchi, H. Nomoto, N. Masaki, M. J. Griffith, S. Mori and M. Kimura, Chem. Commun., 2014, 50, 1941; $(f)$ T. Ikeuchi, S. Agrawal, M. Ezoe, S. Mori and M. Kimura, Chem.-Asian J., 2015, 10, 2347; (g) L. Tejerina, M. V. Martínez-Díaz, M. K. Nazeeruddin and T. Torres, Chem.-Eur. J., 2016, 22, 4369.

14 (a) X. Wang, J. Yang, H. Yu, F. Li, L. Fan, W. Sun, Y. Liu, Z. Y. Koh, J. Pan, W.-L. Yim, L. Yan and Q. Wang, Chem. Commun., 2014, 50, 3965; (b) S.-G. Li, K.-J. Jiang, J.-H. Huang, L.-M. Yang and Y.-L. Song, Chem. Commun., 2014, 50, 4309; (c) D. K. Panda, F. S. Goodson, S. Ray and S. Saha, Chem. Commun., 2014, 50, 5358; (d) K. Kakiage, Y. Aoyama, T. Yano, T. Otsuka, T. Kyomen, M. Unno and M. Hanaya, Chem. Commun., 2014, 50, 6379; (e) A. Amacher, C. Yi, J. Yang, M. P. Bircher, Y. Fu, M. Cascella, M. Grätzel, S. Decurtins and S.-X. Liu, Chem. Commun., 2014, 50, 6540; ( $f$ ) W.-I. Hung, Y.-Y. Liao, T.-H. Lee, Y.-C. Ting, J.-S. Ni, W.-S. Kao, J. T. Lin, T.-C. Wei and Y.-S. Yen, Chem. Commun., 2015, 51, 2152; $(g)$ X. Li, Z. Zheng, W. Jiang, W. Wu, Z. Wang and H. Tian, Chem.
Commun., 2015, 51, 3590; $(h)$ K. Kakiage, Y. i. Aoyama, T. Yano, K. Oya, T. Kyomen and M. Hanaya, Chem. Commun., 2015, 51, 6315; (i) L. Yang, Z. Zheng, Y. Li, W. Wu, H. Tian and Z. Wang, Chem. Commun., 2015, 51, 4842; (j) N. Shibayama, Y. Inoue, M. Abe, S. Kajiyama, H. Ozawa, H. Miura and H. Arakawa, Chem. Commun., 2015, 51, 12795; (k) K. Kakiage, Y. Aoyama, T. Yano, K. Oya, J. Fujisawa and M. Hanaya, Chem. Commun., 2015, 51, 15894.

15 (a) J.-S. Ni, Y.-C. Yen and J. T. Lin, Chem. Commun., 2015, 51, 17080; (b) Y.-D. Lin, B.-Y. Ke, Y. J. Chang, P.-T. Chou, K.-L. Liau, C.-Y. Liu and T. J. Chow, J. Mater. Chem. A, 2015, 3, 16831; (c) S. S. Soni, K. B. Fadadu, J. V. Vaghasiya, B. G. Solanki, K. K. Sonigara, A. Singh, D. Das and P. K. Iyer, J. Mater. Chem. A, 2015, 3, 21664; (d) X. Li, Y. Hu, I. Sanchez-Molina, Y. Zhou, F. Yu, S. A. Haque, W. Wu, J. Hua, H. Tian and N. Robertson, J. Mater. Chem. A, 2015, 3, 2173; (e) Y. Hu, A. Ivaturi, M. Planells, C. L. Boldrini, A. O. Biroli and N. Robertson, J. Mater. Chem. A, 2016, 4, 2509; (f) H. Wu, L. Yang, Y. Li, M. Zhang, J. Zhang, Y. Guo and P. Wang, J. Mater. Chem. A, 2016, 4, 519; (g) J. Wu, G. Li, L. Zhang, G. Zhou and Z.-S. Wang, J. Mater. Chem. A, 2016, 4, 3342; (h) J.-S. Ni, Y.-C. Yen and J. T. Lin, J. Mater. Chem. A, 2016, 4, 6553; (i) A. J. Huckaba, A. Yella, P. Brogdon, J. S. Murphy, M. K. Nazeeruddin, M. Grätzel and J. H. Delcamp, Chem. Commun., 2016, 52, 8424; (j) T.-Y. Li, C. Su, S. B. Akula, W.-G. Sun, H.-M. Chien and W.-R. Li, Org. Lett., 2016, 18, 3386; (k) Y. Gao, X. Li, Y. Hu, Y. Fan, J. Yuan, N. Robertson, J. Hua and S. R. Marder, J. Mater. Chem. A, 2016, 4, 12865.

16 (a) Z. Yao, M. Zhang, H. Wu, L. Yang, R. Li and P. Wang, J. Am. Chem. Soc., 2015, 137, 3799; (b) N. Zhou, K. Prabakaran, B. Lee, S. H. Chang, B. Harutyunyan, P. Guo, M. R. Butler, A. Timalsina, M. J. Bedzyk, M. A. Ratner, S. Vegiraju, S. Yau, C.-G. Wu, R. P. H. Chang, A. Facchetti, M.-C. Chen and T. J. Marks, J. Am. Chem. Soc., 2015, 137, 4414; (c) Y.-S. Yen, J.-S. Ni, T.-Y. Lin, W.-I. Hung, J. T. Lin and M.-C. P. Yeh, Eur. J. Org. Chem., 2015, 7367; (d) H. Jiang, G. Ferrara, X. Zhang, K. Oniwa, A. Islam, L. Han, Y.-J. Sun, M. Bao, N. Asao, Y. Yamamoto and T. Jin, Chem.-Eur. J., 2015, 21, 4065; (e) K. Matsumura, S. Yoshizaki, M. M. Maitani, Y. Wada, Y. Ogomi, S. Hayase, T. Kaiho, S. Fuse, H. Tanaka and T. Takahashi, Chem.-Eur. J., 2015, 21, 9742; (f) K. D. Seo, I. T. Choi and H. K. Kim, Chem.-Eur. J., 2015, 21, 14804; $(g)$ B. Liu, F. Giordano, K. Pei, J.-D. Decoppet, W.-H. Zhu, S. M. Zakeeruddin and M. Grätzel, Chem.-Eur. J., 2015, 21, 18654; (h) Z. Yao, M. Zhang, R. Li, L. Yang, Y. Qiao and P. Wang, Angew. Chem., Int. Ed., 2015, 54, 5994; (i) P. Brogdon, F. Giordano, G. A. Puneky, A. Dass, S. M. Zakeeruddin, M. K. Nazeeruddin, M. Grätzel, G. S. Tschumper and J. H. Delcamp, Chem.-Eur. J., 2016, 22, 694; (j) S. Irie, S. Fuse, M. M. Maitani, Y. Wada, Y. Ogomi, S. Hayase, T. Kaiho, H. Masui, H. Tanaka and T. Takahashi, Chem.Eur. J., 2016, 22, 2507; (k) F.-L. Guo, Z.-Q. Li, X.-P. Liu, L. Zhou, F.-T. Kong, W.-C. Chen and S.-Y. Dai, Adv. Funct. Mater., 2016, 26, 5733. 
17 J. Mao, N. He, Z. Ning, Q. Zhang, F. Guo, L. Chen, W. Wu, J. Hua and H. Tian, Angew. Chem., Int. Ed., 2012, 51, 9873.

18 (a) Y. Ooyama, S. Inoue, R. Asada, G. Ito, K. Kushimoto, K. Komaguchi, I. Imae and Y. Harima, Eur. J. Org. Chem., 2010, 92; (b) Y. Ooyama, S. Inoue, T. Nagano, K. Kushimoto, J. Ohshita, I. Imae, K. Komaguchi and Y. Harima, Angew. Chem., Int. Ed., 2011, 50, 7429; (c) Y. Ooyama, T. Nagano, S. Inoue, I. Imae, K. Komaguchi, J. Ohshita and Y. Harima, Chem.-Eur. J., 2011, 17, 14837; (d) Y. Ooyama, N. Yamaguchi, I. Imae, K. Komaguchi, J. Ohshita and Y. Harima, Chem. Commun., 2013, 49, 2548; (e) Y. Ooyama, Y. Hagiwara, T. Mizumo, Y. Harima and J. Ohshita, New J. Chem., 2013, 37, 2479; (f) Y. Ooyama, T. Sato, Y. Harima and J. Ohshita, J. Mater. Chem. A, 2014, 2, 3293; (g) Y. Ooyama, K. Uenaka and J. Ohshita, Eur. J. Org. Chem., 2015, 3713; (h) Y. Ooyama, K. Uenaka, T. Kamimura, S. Ozako, M. Kanda, T. Koide and F. Tani, $R S C$ Adv., 2016, 6, 16150; (i) Y. Ooyama, K. Furue, T. Enoki, M. Kanda, Y. Adachi and J. Ohshita, Phys. Chem. Chem. Phys., 2016, 18, 30662; (j) Y. Ooyama, N. Yamaguchi, J. Ohshita and Y. Harima, Phys. Chem. Chem. Phys., 2016, 18, 32992.

19 (a) Y. Harima, T. Fujita, Y. Kano, I. Imae, K. Komaguchi, Y. Ooyama and J. Ohshita, J. Phys. Chem. C, 2013, 117, 16364; (b) N. Shibayama, H. Ozawa, M. Abe, Y. Ooyama and H. Arakawa, Chem. Commun., 2014, 50, 6398; (c) Y. Ooyama, K. Uenaka, T. Sato, N. Shibayama and J. Ohshita, RSC Adv., 2015, 5, 2531; (d) J. Ohshita, Y. Adachi, D. Tanaka, M. Nakashima and Y. Ooyama, $R S C$ $A d v .$, 2015, 5, 36673; (e) Y. Harima, Y. Kano, T. Fujita, I. Imae, Y. Ooyama and J. Ohshita, RSC Adv., 2015, 5, 71387; ( $f$ ) Y. Adachi, Y. Ooyama, N. Shibayama and J. Ohshita, Dalton Trans., 2016, 45, 13817.

20 (a) D. Daphnomili, G. D. Sharma, S. Biswas, T. K. R. Justin and A. G. Goutsolelos, J. Photochem. Photobiol., A, 2013, 253, 88; (b) J. Lu, X. Xu, Z. Li, k. Cao, J. Cui, Y. Zhang, Y. Shen, Y. Li, J. Zhu, S. Dai, W. Chjen, Y. Cheng and M. Wang, Chem.-Asian J., 2013, 8, 956; (c) M.-D. Zhang, H.-X. Xie, X.-H. Ju, L. Qin, Q.-X. Yang, H.-G. Zheng and X.-F. Zhou, Phys. Chem. Chem. Phys., 2013, 15, 634; (d) D. Daphnomili, G. Landrou, P. Singh, A. Thomas, K. Yesudas, B. K. G. D. Sharma and A. G. Goutsolelos, RSC $A d v .$, 2012, 2, 12899; (e) L. Wang, X. yang, S. Li, M. Cheng and L. Sun, $R S C A d v ., 2013,3,13677 ;(f)$ T. Sakurada, Y. Arai and H. Segawa, RSC Adv., 2014, 4, 13201; $(g)$ J. Mao, D. Wang, S.-H. Liu, Y. Hang, Y. Xu, Q. Zhang, W. Wu, P.-T. Chou and J. Hua, Asian J. Org. Chem., 2014, 3, 153; (h) T. Ikeuchi, S. Agrawal, M. Ezoe, S. Mori and M. Kimura, Chem.-Asian J., 2015, 10, 2347.

21 (a) C. Stangel, A. Bagaki, P. A. Angaridis, G. Charalambidis, G. D. Sharma and A. G. Coutsolelos, Inorg. Chem., 2014, 53, 11871; (b) M. N. K. P. Bolisetty, C.-T. Li, K. R. J. Thomas, G. B. Bodedla and K.-C. Ho, Tetrahedron, 2014, 70, 4203; (c) D. Franchi, M. Calamante, G. Reginato, L. Zani, M. Peruzzini, M. Taddei, F. F. de Biani, R. Basosi, A. Sinicropi, D. Colonna, A. Di Carlo and A. Mordin, Tetrahedron, 2014, 70, 6285; (d) E. V. Verbitskiy,
E. M. Cheprakova, J. O. Subbotina, A. V. Schepochkin, P. A. Slepukhin, G. L. Rusinov, V. N. Charushin, O. N. Chupakhin, N. I. Makarova, A. V. Metelitsa and V. I. Minkin, Dyes Pigm., 2014, 100, 201; (e) C.-L. Mai, T. Moehl, C.-H. Hsieh, J.-D. Décoppet, S. M. Zakeeruddin, M. Grätzel and C.-Y. Yeh, ACS Appl. Mater. Interfaces, 2015, 7, 14975; (f) H. Jia, K. Shen, X. i. Ju, M. Zhanga and H. Zheng, New J. Chem., 2016, 40, 2799; $(g)$ P. A. Angaridis, E. Ferentinos, G. Charalambidis, K. Ladomenou, V. Nikolaou, S. Biswas, G. D. Sharma and A. G. Coutsolelos, RSC Adv., 2016, 6, 22187; (h) U. Meinhardt, F. Lodermeyer, T. A. Schaub, A. Kunzmann, P. O. Dral, A. C. Sale, F. Hampel, D. M. Guldi, R. D. Costa and M. Kivala, RSC Adv., 2016, 6, 67372.

22 H. He, A. Gurung and L. Si, Chem. Commun., 2012, 48, 5910. 23 (a) S. Hattori, K. Ohkubo, Y. Urano, H. Sunahara, T. Nagano, Y. Wada, N. V. Tkachenko, H. Lemmetyineu and S. Fukuzumi, J. Phys. Chem. B, 2005, 109, 15368; (b) S. Erten-Ela, M. D. Yilmaz, B. Icli, Y. Dede, S. Icli and E. U. Akkaya, Org. Lett., 2008, 10, 3299; (c) S. Kolemen, Y. Cakmak, S. Erten-Ela, Y. Altay, J. Brendel, M. Thelakkat and E. U. Akkaya, Org. Lett., 2010, 12, 3812; (d) S. Kolemen, O. A. Bozdemir, Y. Cakmak, G. Barin, S. Erten-Ela, M. Marszalek, J.-H. Yum, S. M. Zakeeruddin, M. K. Nazeeruddin, M. Grätzel and E. U. Akkaya, Chem. Sci., 2011, 2, 949; (e) M. Mao, J.-B. Wang, Z.-F. Xiao, S.-Y. Dai and Q.-H. Song, Dyes Pigm., 2012, 94, 224; $(f)$ J.-B. Wang, X.-Q. Fang, X. Pan, S.-Y. Dai and Q.-H. Song, Chem.-Asian J., 2012, 7, 696.

24 (a) D. Hablot, A. Islam, L. Han and R. Ziessel, ChemPlusChem, 2012, 77, 462; (b) C. Qin, A. Mirloup, N. Leclerc, A. Islam, A. El-Shafei, L. Han and R. Ziessel, Adv. Energy Mater., 2014, 4, 1400085; (c) M. Mao and Q.-H. Song, Chem. Rec., 2016, 16, 719; (d) J.-F. Lefebvre, X.-Z. Sun, J. A. Calladine, M. W. George and E. A. Gibson, Chem. Commun., 2014, 50, 5258; (e) Y. Kubo, D. Eguchi, A. Matsumoto, R. Nishiyabu, H. Yakushiji, K. Shigaki and M. Kaneko, J. Mater. Chem. A, 2014, 2, 5204; (f) C. J. Wood, G. H. Summers and E. A. Gibson, Chem. Commun., 2015, 51, 3915; $(g)$ B. L. M'Sabah, M. Boucharef, J. Warnan, Y. Pellegrin, E. Blart, B. Lucas, F. Odobel and J. Bouclé, Phys. Chem. Chem. Phys., 2015, 17, 9910; (h) Y. Çakmak, S. Kolemen, M. Buyuktemiz, Y. Dede and S. Erten-Ela, New J. Chem., 2015, 39, 4086; (i) Z. E. Galateia, N. Agapi, N. Vasilis, G. D. Sharma and C. G. Athanassios, J. Mater. Chem. C, 2015, 3, 5652; (j) G. H. Summers, J.-F. Lefebvre, F. A. Black, E. S. Davies, E. A. Gibson, T. Pullerits, C. J. Wood and K. Zidek, Phys. Chem. Chem. Phys., 2016, 18, 1059.

25 (a) M. Mao, X.-L. Zhang, X.-Q. Fang, G.-H. Wu, Y. Ding, X.-L. Liu, S.-Y. Dai and Q.-H. Song, Org. Electron., 2014, 15, 2079; (b) S. P. Singh and T. Gayathri, Eur. J. Org. Chem., 2014, 4689; (c) M. Mao, X. Zhang, L. Cao, Y. Tong and G. Wu, Dyes Pigm., 2015, 117, 28; (d) Y.-D. Lin, B.-Y. Ke, Y. J. Chang, P.-T. Chou, K.-L. Liau, C.-Y. Liu and T. J. Chow, J. Mater. Chem. A, 2015, 3, 16831; (e) I. Gonzalez-Valls, A. Mirloup, T. Le Bahers, N. Keller, 
T. Cottineau, P. Sautet and V. Keller, RSC Adv., 2016, 6, 91529; (f) N. Kaneza, J. Zhang, H. Liu, P. S. Archana, Z. Shan, M. Vasiliu, S. H. Polansky, D. A. Dixon, R. E. Adams, R. H. Schmehl, A. Gupta and S. Pan, J. Phys. Chem. C, 2016, 120, 9068; $(g)$ Z. Lu, M. Liang, P. Dai, K. Miao, C. Zhang, Z. Sun and S. Xue, J. Phys. Chem. C, 2016, 120, 25657; (h) J. Zhang, F. Lu, S. Qi, Y. Zhao, K. Wang, B. Zhang and Y. Feng, Dyes Pigm., 2016, 128, 296; (i) H. Cheema, R. Younts, B. Gautam, K. Gundogdu and A. El-Shafei, Mater. Chem. Phys., 2016, 184, 57.

26 A. Mirloup, P. Retailleau and R. Ziessel, Tetrahedron Lett., 2013, 54, 4456.

27 C. D. Fiandra, M. Moccia, V. Cerullia and M. F. A. Adamo, Chem. Commun., 2016, 52, 1697.

28 Both the geometry optimization and energy calculation were performed by employing the density functional theory (DFT), at the level of B3LYP/6-31G(d,p) on the Gaussian09 program package (M. J. Frisch, G. W. Trucks, H. B. Schlegel,
G. E. Scuseria, M. A. Robb, J. R. Cheeseman, G. Scalmani, V. Barone, B. Mennucci, G. A. Petersson, H. Nakatsuji, M. Caricato, X. Li, H. P. Hratchian, A. F. Izmaylov, J. Bloino, G. Zheng, J. L. Sonnenberg, M. Hada, M. Ehara, K. Toyota, R. Fukuda, J. Hasegawa, M. Ishida, T. Nakajima, Y. Honda, O. Kitao, H. Nakai, T. Vreven, J. A. Montgomery Jr, J. E. Peralta, F. Ogliaro, M. Bearpark, J. J. Heyd, E. Brothers, K. N. Kudin, V. N. Staroverov, R. Kobayashi, J. Normand, K. Raghavachari, A. Rendell, J. C. Burant, S. S. Iyengar, J. Tomasi, M. Cossi, N. Rega, J. M. Millam, M. Klene, J. E. Knox, J. B. Cross, V. Bakken, C. Adamo, J. Jaramillo, R. Gomperts, R. E. Stratmann, O. Yazyev, A. J. Austin, R. Cammi, C. Pomelli, J. W. Ochterski, R. L. Martin, K. Morokuma, V. G. Zakrzewski, G. A. Voth, P. Salvador, J. J. Dannenberg, S. Dapprich, A. D. Daniels, O. Farkas, J. B. Foresman, J. V. Ortiz, J. Cioslowski and D. J. Fox, Gaussian 09, Revision A.02, Gaussian, Inc., Wallingford CT, 2009). 